\title{
Histopathological changes in liver of fish Channa punctatus (Bloch) exposure in effluents of Bhilai steel plant C.G. (India)
}

\author{
Alka Mishra \\ Govt. V.Y.T. P.G. Autonomous College Durg C.G. (India) \\ Available online at: www.isroset.org \\ Received: 28/Mar/2019, Accepted: 10/Apr/2019, Online: 30/Apr/2019
}

\begin{abstract}
Environmental pollution is one of the most serious problems facing humanity and other life forms on our planet today. Since millions of years, natural resources had been stored virtually untouched in the Earth, but, within a period of a few hundred years, the onset of the industrial revolution led to massive exploitation of a vast amount of these resources at unimaginable rates. The result was the generation of large amounts of waste going straight in to the environment, seriously damaging its natural processes. This types of wastes if discharged directly in to the environment without treatment, some of these pollutants are responsible for various acute and chronic diseases, such as skin burns and rashes, bone abnormalities, lung and digestive system disorders in aquatic and surrounding land fauna. In the present study we want to find out the impact of effluents of Bhilai steel plant on the liver of fish Channa punctatus ..After the study we find that the Toxicants produce pathological changes on the fish liver such as necrobiotic lesions,damage in tissues vascular congestion and cellular degeneration in the in the liver of fish exposed to different concentration (10\%,20\% and 30\%) of effluents of Bhilai steel plant for one month exposure.
\end{abstract}

Keyword - Histo pathology ,liver, effluent, Bhilai steel plant

\section{INTRODUCTION}

The Bhilai Steel Plant, a unit of Steel Authority of India Ltd. and a public sector undertaking was conceived under aegis of Indo-USSR Treaty in the 2nd Five year plan in 1959. The plant is located at the central position of India, which is one of the major iron belts of India and is about 40 kilometer from Raipur, capital of the state of Chhattisgarh. With a production capacity of 1.0 million tons of steel, it is the largest steel plant in India. Besides the major marketable product which is good quality steel, it also produces important by products, such as, Coal tar, Naphthalene and Benzol. During the production of such types of important elements some waste water were generated from the cooling of the coke oven gases which are a important part of steel industries The major wastewater streams are generated from the cooling of the coke oven gas and the processing of ammonia, tar, naphthalene, phenol, and light oil. Besides liquid wastes, solid wastes other than coke breeze (which averages $1 \mathrm{~kg} / \mathrm{t}$ of product) are also generated. Most of the solid wastes contain hazardous components such as benzene and the conventional contaminants like phenol, cyanide, ammonia, thiocyanates, thiosulphates, tar, oil and grease and trace contaminants like PAH (Poly Aromatic Hydrocarbons), phthalate esters and heterocyclic nitrogenous compounds present in the wastewater are reported to have adverse effects on aquatic fauna and indirectly on human lives ${ }^{1}$

The liver is the largest gland of the body which plays a primary and important role in the metabolism and excretion of xenobiotic compounds with morphological alterations occurring in some toxic conditions ${ }^{2}$.It also acts as storage center for many substances ${ }^{3}$.Fish liver is a very interesting organ for study of the interactions between environmental factors and hepatic structures and functions ${ }^{4}$

${ }^{5}$.It is the site of glycogen synthesis, storage and deamination of amino acid .Several proteins, including those required for blood clotting, are also synthesized in the liver cells. ${ }^{6}$ some researchers observed that the liver of fish subjected to phenol showed high score of histopathological symptoms such as inflammation, central necrosis and cell degeneration. Several workers, namely, $\mathbf{7 , 8 , 9 , 1 0 , 1 1}$ have studied the histopathological alterations in tissues of fishes in response to pollutants. Histopathological effects of pesticides have been also studied ${ }^{12,13,14,15,16}$ Besides,this some, have studied the effect of industrial effluents on fishes ${ }^{17}$. Several other investigators have reported the accumulated metal ions of industrial effluents to induce many pathological conditions ${ }^{18,19}$ Further, the histopathological picture of the organ can corroborate with the biochemical changes accounting for the functional disruption of the activity of the organs due to cellular damage ${ }^{20,21,22}$. 


\section{MATERIAL AND METHODS}

The fishes were acclimatized and exposed to various concentrations of the toxicants for one month and tissues for histopathology were collected separately from 4 live fishes belonging to each group at 1 week intervals by mid-ventral incision. The visceral organs were taken out and examined individually in petridishes and collection of fresh samples of target organs, done in normal saline.

The tissues were cut into small pieces and placed in $10 \%$ ice cold formalin for 24 hours immediately after removal from the body .They were then washed in running tap water overnight and subsequently dehydrated through graded alcohol series, cleared in xylene and embedded in Paraffin wax at 58 to $60^{\circ} \mathrm{C}$ for preparation of blocks. Sections of $8 \mu$ thickness were cut and ribbons obtained were gently placed on slides smeared with Mayer's albumin. Deparaffinization of sections was done in Xylene followed by hydration through descending grades of alcohol; the sections were then brought to water and stained Haematoxylin and Eosin.

\section{RESULTS}

Histopathological changes studied in both control and treated groups indicated incidence of damage in tissues after exposure to effluent for short term and long terms in low and high concentration . Liver from control fishes were observed to be darker in color and exhibited a normal compact architecture with polygonal hepatocytes presenting a homogenous cytoplasm and clearly visible central blood vessels in the first week Although, no lesions were observed in response to short term exposures different concentrations of toxicants, $(10 \%, 20 \%, 30 \%$ concentration of effluents of plant) however remarkable changes in liver structure were observed in response to long term exposure.

Although ,no visible changes were observed upon exposure to $10 \%$ effluent ,however, degenerative changes in liver tissue were observed in the $3^{\text {rd }}$ week after exposure followed by vascular congestion, hemorrhage and degeneration in the 4rth week after exposure

Exposure to $20 \%$ effluent shows the progression of vascular congestion, cellular degeneration and hemorrhage in the $2^{\text {nd }}, 3^{\text {rd }}$ and 4 rth week after exposure. Similar changes are also observed in response .Fatty degeneration and necrotic changes were observed in the 4rth week. Similar changes were also observed in response to exposure to $30 \%$ effluent

\section{DISCUSSION}

Although, no lesions were observed in response to different concentrations of the toxicants, however similar but remarkable changes in liver structure were observed in response to exposures. These included onset of nuclear and cytoplasmic degenerations in the form of hydropic change followed by leucocytic infiltration, vascular congestion, hemorrhage, fatty degeneration and necrotic changes which were observed to be accelerated with increasing concentration of the toxicant which proves beyond doubt that hepatocytes are the primary targets of toxic lesions. Presence of shrunk and pyknotic nuclei may be indicative of functional degradation of liver cells.

Similar histopathological changes in the form of vacuolar degeneration of hepatocytes, focal necrosis, thrombosis of central vessels, dilation and congestion of blood sinusoids and fibrosis in liver of Tillapia zilli and Solea vulgaris have been reported by ${ }^{23}$ who attributed this to direct action of pollutants. Similarly, congestion of central vein, vacoulation of hepatocyte, oedema, cellular infiltration and cellular necrosis in Clarias gariepinus exposed to detergent effluent was also observed by ${ }^{24}$ also reported cellular vacuolization with hypertrophy of hepatocytes in advanced cases of Lindane toxicity. Cloudy swelling of hepatocytes, congestion, vacuolar degeneration, karyolysis, karyohexis, dilation of sinusoids and nuclear hypertrophy have been reported in response to Dichlorvos ${ }^{25,26}$, also studied the histopathological effect of phenol on liver of Oreochromis aureus juveniles and reported the presence of inflammation, central necrosis and cell degeneration.

Cytopathological alterations in hepatocytes of fish following exposure to xenobiotic compounds represent a powerful tool to reveal sub lethal effects of chemicals and to elucidate underlying modes of action. Liver and hepatocytes are considered as efficient biomarkers of contaminant exposure because the liver organ is central to numerous vital functions in basic metabolism ${ }^{\mathbf{2 7 , 2 8 , 2 9}}$,.It is also the major site of accumulation ,biotransformation and excretion of xenobiotic compounds, besides being a major site of Cyt P450 mediated mixed fraction oxygenase system ${ }^{30}$. Bile produced in hepatocytes and released into the proximal portion of intestine serves as a carrier of conjugated toxins ${ }^{31}$ Besides it is also a site of exogenous vitellogenesis ${ }^{32}$ enabling transfer and storage of toxicants in the yolk of embryo. Thus hepatocytes are primary targets of toxic lesions ${ }^{33}$.

\section{REFERENCES}

[1]. Prasad B. and Singh G.(1989): Characterization of Coke Plant effluents with subsequent treatment-An Appraisal. Indian Journal of Environmental Protection, 9 (7): 525-530.

[2]. Roch, E. and Monteiro, R.A.F. ( 1999): Histology and cytology of fish liver.A review; In: Saksena, D.N. (ed) Icthyology. Recent research advances science publishers Enfield, New Hampshire. 321-344.

[3]. Takashima, F. \& T. Hibya. (1995): An atlas of fish histology: normal and pathological features, 2nd ed. Tokyo, Kodansha. 
[4]. Brusle, J. and Anadon G. (1996): The structure and function of fish liver.In fish morphology (eds.) J.S.D., 77-93.

[5]. Velkova-jordonaska, L. and G. Kostoskj (2005): Histopathological analysis of liver in fish (Barbus meridionalis) in reservoir Trebenita. Nat.eroat.,14: 147-153. (cited in El Bakary \& El Gammal, 2010

[6]. Abdel-Hameid, N. A. H. (1994): Effect of some pollutants on biological aspects of Oreochromis niloticus. M. Sc. thesis, Benha Branch: Faculty of Science, Zigazig University

[7]. Haniffa, M. A., Sundaravadanam, S. (1984): Effects of distillery effluent on histopathological changes in certain tissues of Barbus stigma . Life Sci. Adv., 2: 142-146

[8]. Kumari, S., Anstha, and M. S. R., Kumar (1997): Histopathological alteration's induced by aquatic pollutant's in channa punctatus from Hussain sagar lake (A.P.) J. Environ. Biol . 18(1): 11-16.

[9]. Das , B.C. and Mukherjee, S.C. (2000): A histopathological study of carp (Labeo rohita) exposed to hexchlorocyclohexane.Veteoninarski Archiv 70 (4): 169-180

[10]. Fatma, A. S. M. ( 2009): Histopathological studies on Tilapia zillii and Solea vulgaris from Lake Qarun, Egypt. World Journal Fish and Marine Sciences, 1(1): 29-39.

[11]. Ravanaiah and Murthy (2010 Ravanaiah G; Murthy, C. V. N. (2010): Impact of aquaculture and industrial pollutants of Nellore district on the histopathological changes in the liver and intestine tissues of fish, Tilapia mossambica, 7(2): 117-22 .

[12]. Banerjee, S. and Bhattacharya, S. (1995): Histopathological changes induced by chronic nonlethal level of Elesan, Mercury and Ammonia in the small intestine of Channa punctatus. Ecotoxicol. Eviron. Safety., 31: 62-68.

[13]. Mercy, T. V. A., B. Madhusoodana , J. R. Nair (1996): Pesticide induced histological changes in juveniles of Channa marulius. Fourt. Ind. Fisheries. Forum.pp 81

[14]. Ortiz J. B., De Chnales,M.G. and Sarssquete,C. (2003): Histopathological changes induced by lindane (gamma-HCH) in various organs of fishes. Sci . 67: 53-61

[15]. Sakr, S.A.and Jamal Al Lail,S.M. (2005): Fenvalerate induced Histopathological and Histochemical changes in the liver of the cat fish Clarias gariepinus. Journal of Applied Science Research 1(3): 263-267.

[16]. Butchiram,M.S., Tilak, K.S. and Raju, P. W. (2009): Studies on histopathological changes in the gill, liver and kidney of Channa punctatus (Bloch) exposed to Alachlor. J. Environ. Biol.ISSN : 0254-8704 30(2): 303-306.

[17]. Muley, D. V., Karanjkar, D.M., Maske, S.V. (2007): Impact of industrial effluents on the biochemical composition of Fresh water fish Labeo rohita. Biol.28 (2): 245-249

[18]. Mathivanan, V. (1998): The impact of heavy metals cadmium copper and zinc on the physiology of freshwater fish, Anabas. testudeneus . Ph.D. thesis, Annamalai University, India

[19]. Jagadeesan, G. (1994): Studies on the toxic effects of mercuric chloride and the influence of antidote dimercaptol on selected tissues in Labeo rohita (Hamilton) fingerlings. Ph.D., Thesis,Annamalai University, India

[20]. Muniyan,V. (1999): Effect of Ethofennprox (Frebon) on the biochemical and histopathological changes in the selected tissues of the fresh water fish, Oreochromis mossambicas (Peters) Ph.D. Thesis, Annamalai University, India

[21]. Tilak, K. S., K., Veeraiah and D. Koteswara, Rao (2005 b): Histopathological changes in the gill, liver, brain and kidney of the Indian major carp Cirrhinus mrigala (Hamilton) exposed to chloropyrifos. Pollut. Res., 24: 101-111

[22]. Couch, J. A. (1975): Histopathological effects of pesticides and related chemicals on liver and pancreas of fish. In: The Pathology of Fishes, Riblin, W.E. and G. Migaki (Eds.). University of Wisconsin Press, Madison Wisconsin,: 515-558

[23]. Fatma, A. S. M. ( 2009): Histopathological studies on Tilapia zillii and Solea vulgaris from Lake Qarun, Egypt. World Journal Fish and Marine Sciences, 1(1): 29-39.

[24]. Ortiz J. B., De Chnales,M.G. and Sarssquete,C. (2003): Histopathological changes induced by lindane (gamma-HCH) in various organs of fishes. Sci . 67: 53-61.

[25]. Velmurugan, B., Selvanayagam, M., Cengiz, E. I., Unlu, E. (2007): The effects of Fenvalerate on different tissues of freshwater fish Cirrhinus mrigala.J.Environ.Sci.Health.42: 157163.

[26]. Abdel-Hameid, N. A. H. (1994): Effect of some pollutants on biological aspects of Oreochromis niloticus. M. Sc. thesis, Benha Branch: Faculty of Science, Zigazig University

[27]. Arias, J. M., Dopper, H. Schachter, D. and Schatritz, D. A. (1998): The liver biology and pathology biology. Raven press, New York 664 pp.

[28]. Gingerich, W. H. (1982): Hepatic toxicology of fishes. In Aquatic Toxicology, ed. L. F.Weber, New York, Plenum Press. 55-105.

[29]. Moon, T.W., Walsh, P.J., Mommsen, T.P. (1985): Fish hepatocytes: A model metabolic system.Can.Jour.Fish Aquatic.Sci.,42:1772-1782.(cited in Braunbeck,1998).

[30]. Lester, S. M., Braunbeck, T., Tehg, S. J., Stegman, J. J., Miller, M .R (1993): Hepatic cellular distribution of cytochrome Cyp IA in rainbow trout (on) an immunohisto- and cytochemical study. Cancer Res., 53: 3700-3706.

[31]. Schmidt, D., Fletcher, C. D. M. and Harms, D. (1993): Rhabdomyosarcomas with primary presentation in the skin. Pathol Res Pract 189: 422 - 427

[32]. Anderson, M. J, Olsen, H. Matsumara, F., and Hinton, D. E. (1996): In vivo modulation of $17 \beta$ estradiol induced vitellogenin synthesis and estrogen receptor in rainbow trout (Onchorhynchus mykiss) livercells by $\beta$ naphthoflavone. Toxicol. Appli.Pharmacol.,137: 210-218 (Cited in Braunbeck,1998)

[33]. Braunbeck, T. (1998): Cytological alterations in fish hepatocytes following in vivo and in vitro sublethal exposure to xenobiotics structural biomarkers of environmental contamination. In: Braunbeck, T., Hinton, D.E., Streit, B. (eds.) Fish ecotoxicology. Birkhäuser, Basel, pp. 61-140. 


\section{ABBREVIATIONS USED IN PLATES}

\begin{tabular}{|c|c|c|c|}
\hline 1. $\mathrm{BH}$ & hemorrhage & 2. BS & Blood sinusoid \\
\hline 3. BV & Blood vessels & 4. $\mathbf{C N}$ & Central necrosis \\
\hline 5. DC & Degenerated cytoplasm & 6. DN & Degeneration in nucleus \\
\hline 7. DCV & Degeneration of central vein & 8. DEC & Damage in Epithelial cell \\
\hline 9. DH & Degeneration of hepatocyte & 10. DS & Degeneration in sinusoid \\
\hline 11. $\mathrm{HC}$ & Hepatocyte & 12. HP & Hepatopancreas \\
\hline 13. ICS & Inter cellular space & 14. IVH & Intra vascular haemolysis \\
\hline
\end{tabular}

Fig .1.Impact of $10 \%$ effluents on liver of fish Channa punctatus.

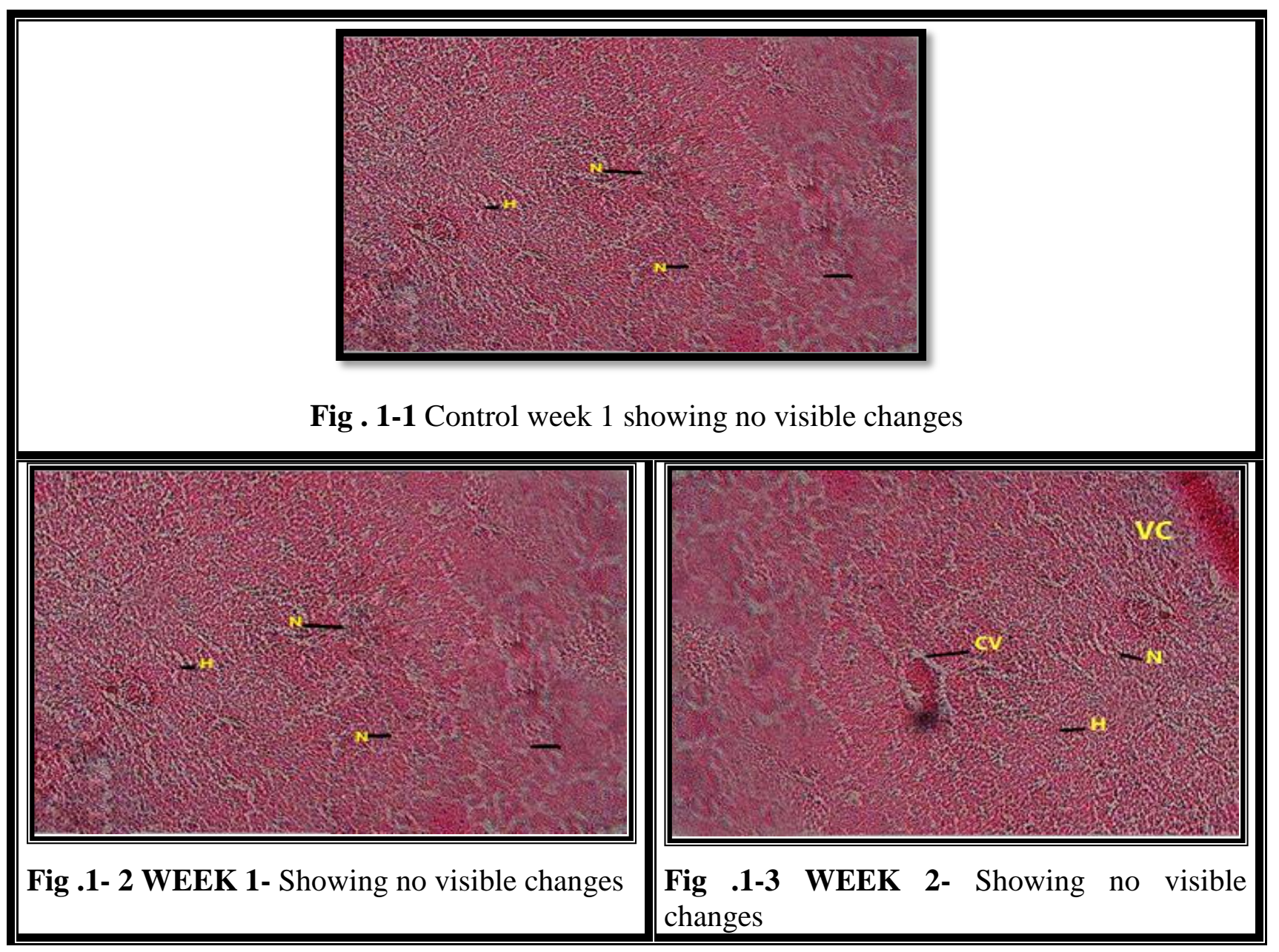




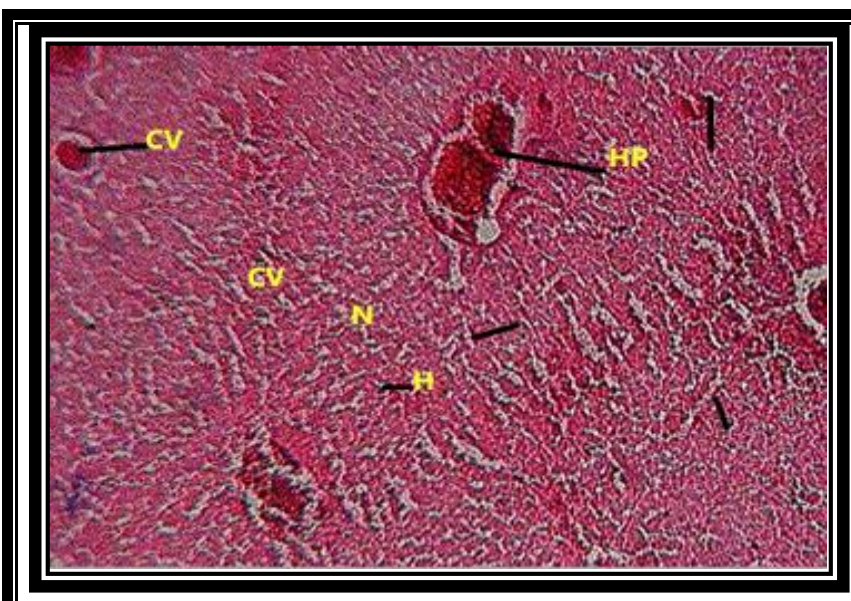

Fig .1-4 WEEK 3 - Showing degenerated liver tissue

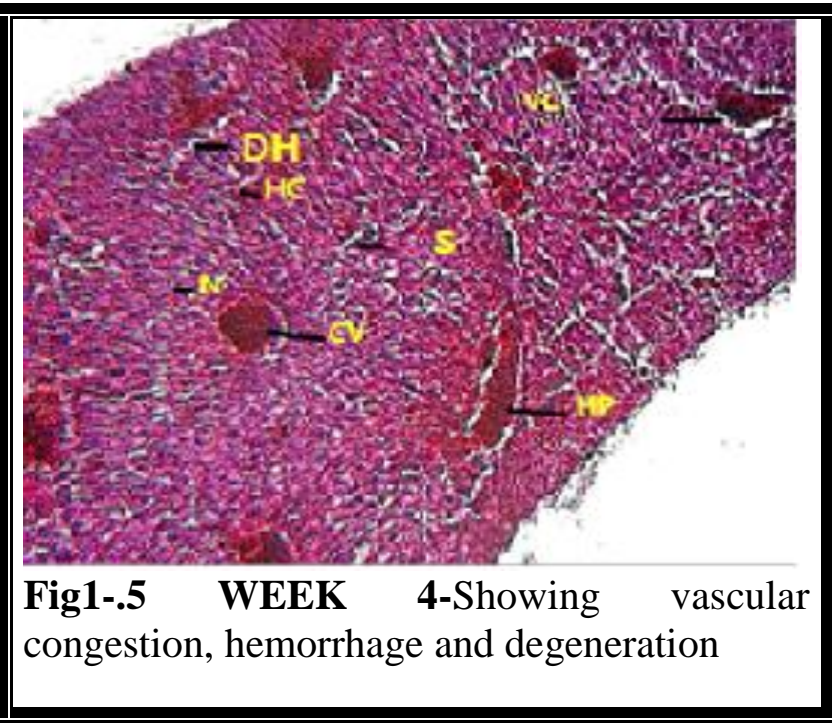

Fig .2.Impact of $20 \%$ effluents on liver of fish Channa punctatus

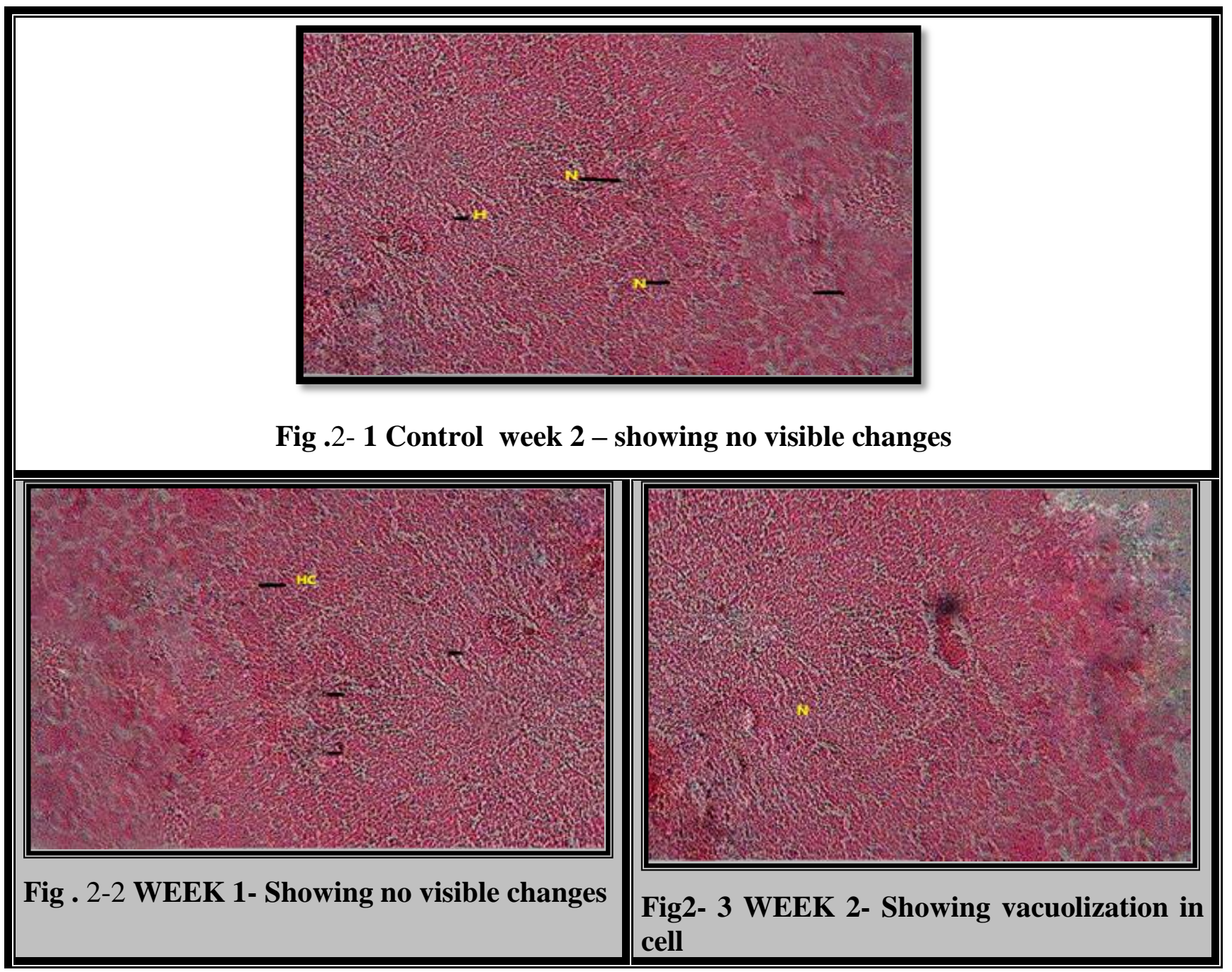




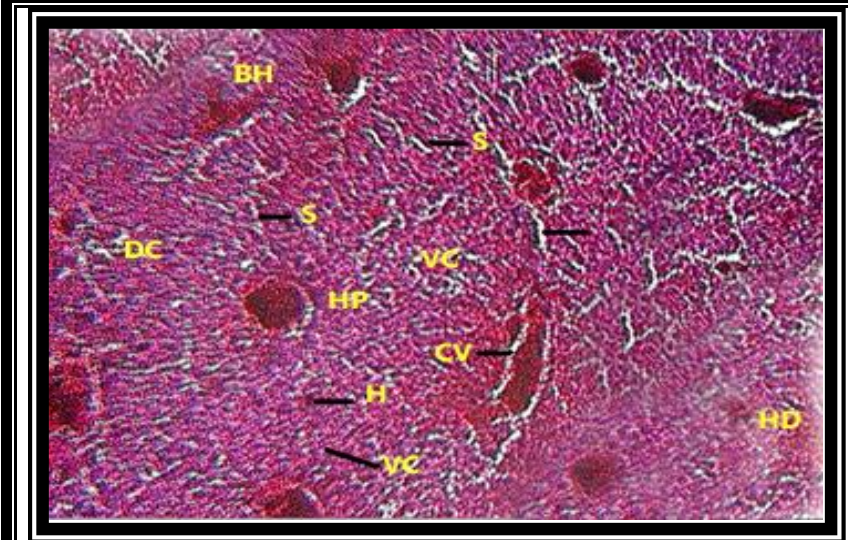

Fig 2-4 WEEK 3- Showing vacuolar degeneration and hemorrhage

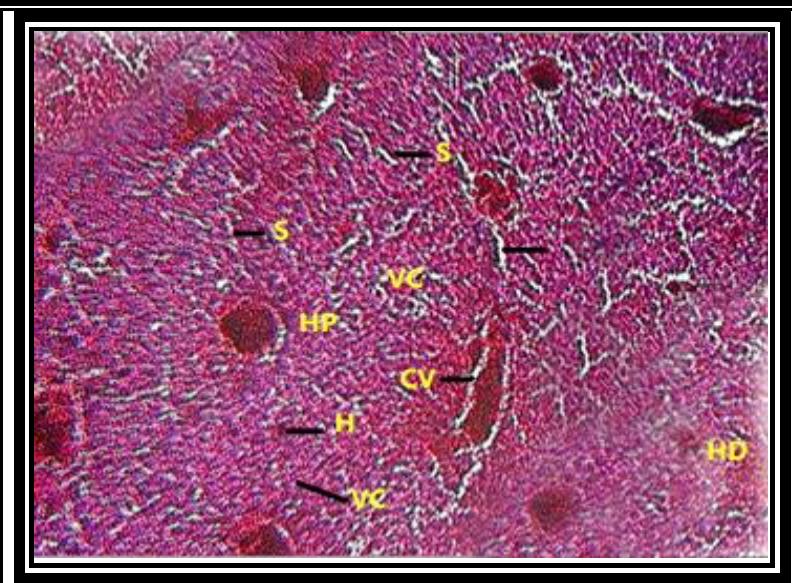

Fig 2-5 WEEK 4 -Showing vascular congestion, hemorrhage and tissue degeneration

Fig . 3.Impact of 30\% effluents on liver of fish Channa punctatus

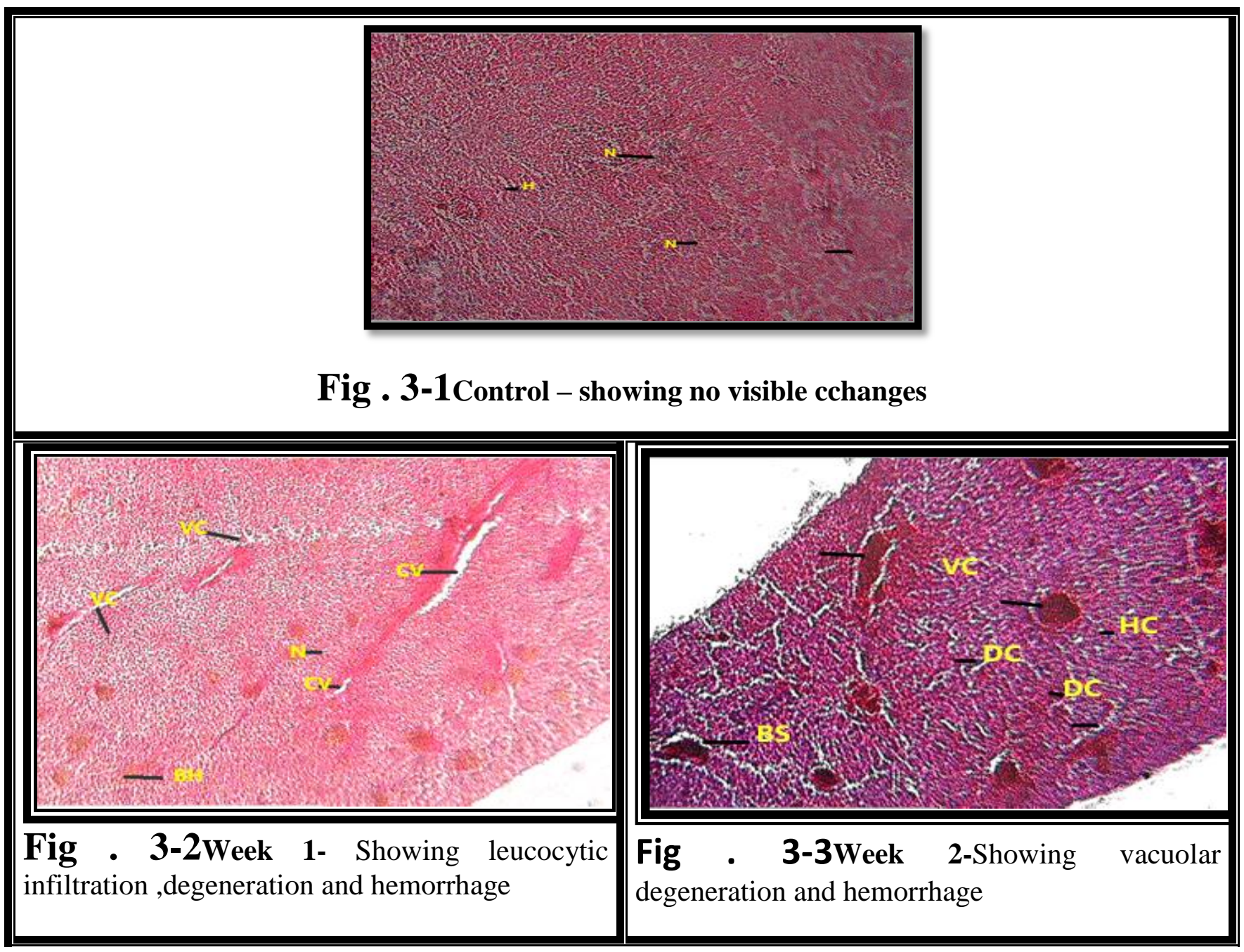




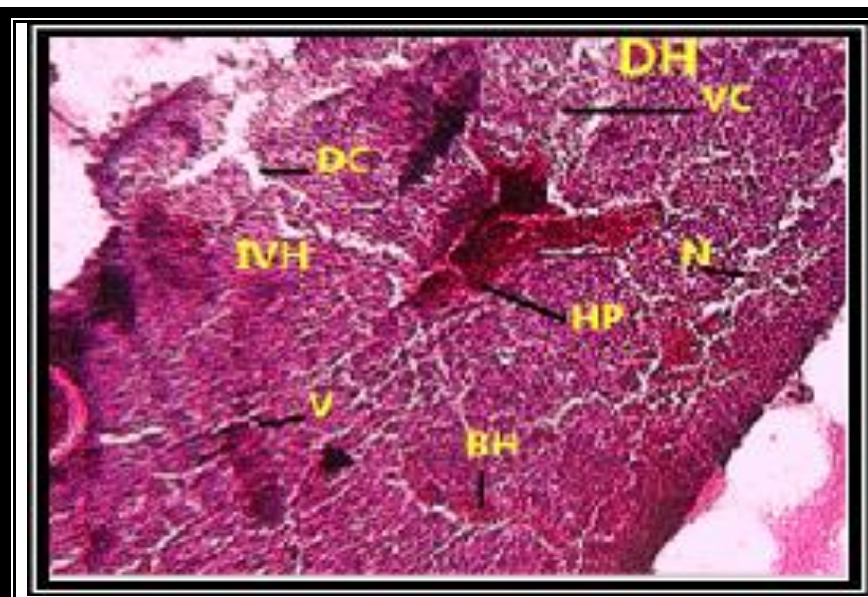

Fig . 3-4Week 3-Showing degeneration and necrosis

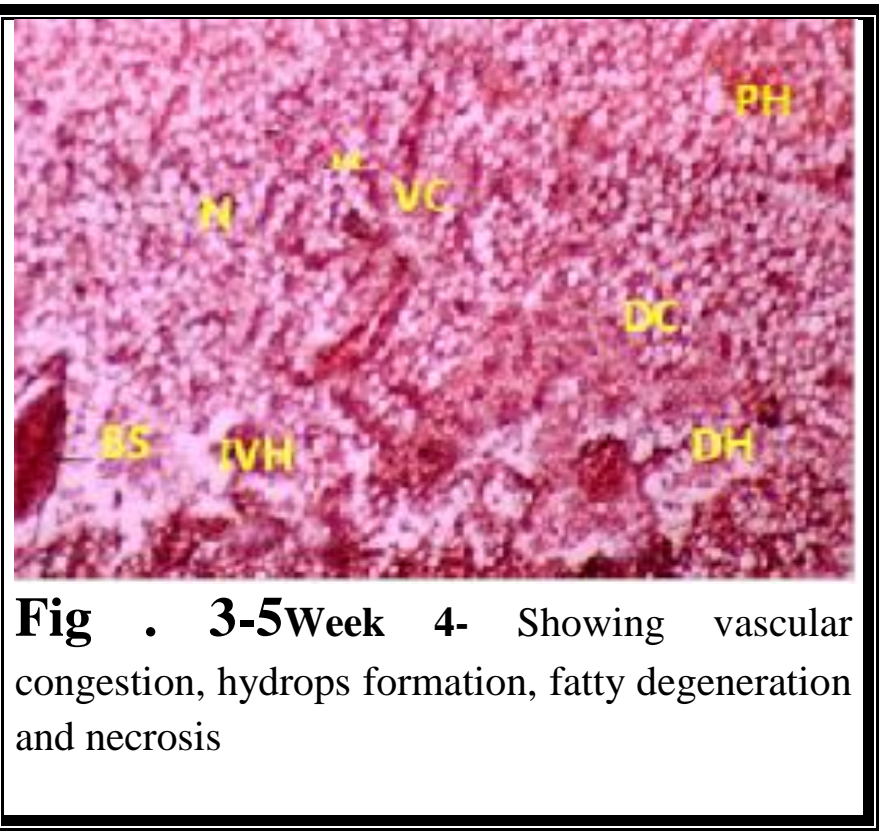

